\title{
FAKE NEWS: UM EXAME SEMIOLINGUÍSTICO DA DESINFORMAÇÃO EM AMBIENTES SOCIOINTERATIVOS DIGITAIS
}

\author{
Alexandre Henrique dos Santos Monteiro ${ }^{\mathrm{a}}$ \\ Ilana da Silva Rebello ${ }^{\mathrm{b}}$
}

\begin{abstract}
RESUMO
O presente trabalho tem o objetivo de examinar, sob à luz da Teoria Semiolinguística de Patrick Charaudeau, em uma postagem de Facebook, as intencionalidades psicosociodiscursivas que determinam as orientaçóes discursivas expressas pelas visadas, bem como os procedimentos de construção enunciativa de ordem linguística que explicitam os diferentes tipos de relaçóes do ato enunciativo.
\end{abstract}

PALAVRAS-CHAVE: Semiolinguística; visadas; fake news.

Recebido em: 10/04/2019

Aprovado em: 02/10/2019

\section{Considerações iniciais}
inegável que a tecnologia computacional, potencializada pela internet, criou uma imensa rede social virtual que desconhece limites físicos de distância, permitindo que pessoas se relacionem de forma síncrona (MARCUSCHI, 2010), criando um vasto ambiente de onde emergem novas relações sociointerativas, uma vez que "todas as tecnologias comunicacionais novas geram ambiente e meio novos" (MARCUSCHI, 2010, p. 31).

\footnotetext{
a Mestrando do PPG Estudos de Linguagem UFF. E-mail: euverbo@hotmail.com.

b Professora Adjunta IV do GLC - UFF. E-mail: ilanarebello@id.uff.br.
} 
Essa revolução digital acarretou a passagem do mass media (simbolizados por TV, rádio, imprensa) para formas individualizadas de produção, difusão e estoque de informação, que segue uma estrutura multidirecional do tipo "todos-todos" (LEMOS, 2015). É nessa nova configuração sociointerativa que nascem comentaristas da vida, que manipulam a opinião coletiva ao difundirem saberes de opiniáo como se fossem saberes de conhecimento (CHARAUDEAU, 2016).

Ao defenderem uma crença diante de um grupo, esses comentaristas pretendem que essa ideia seja partilhada pelos outros, e isso faz com que a opinião seja expressa na forma de um enunciado "verdadeiro", portador de um ponto de vista geral, de uma crença supostamente comum. (CHARAUDEAU, 2016)

Nesse contexto, as instâncias do mundo político e midiático dedicam-se a homogeneizar as opinióes coletivas por meio de comentários, declaraçóes peremptórias, com veracidade comprovada (ou não), para, posteriomente, apropriarem-se delas (CHARAUDEAU, 2016).

Noam Chomsky, em Midia: propaganda e manipulação (2013), narra os primórdios da estratégia da desinformação na propaganda política em nossa era, por meio da propaganda no governo Woodrow Wilson, que estava intensamente comprometido com a Primeira Grande Guerra e conseguiu, com a constituição da comissão Creel, em seis meses, transformar uma nação com ideias até então pacíficas em uma população histérica e belicosa, que temia um possível Perigo Vermelho representado pela União Soviética. Houve grande apoio por parte da mídia e dos líderes empresariais que lançaram mão dos instrumentos mais diversos:

Inventaram, por exemplo, que os humanos cometiam uma série de atrocidades, como arrancar os braços de bebês belgas, e toda sorte de fatos horripilantes que ainda podem ser encontrados em alguns livros de história. Boa parte desse material foi crida pelo Ministério da propaganda britânico, dedicado à época como consta de suas resoluçóes secretas - 'a controlar a opiniáo da maior parte do mundo'. (CHOMSKY, 2013, p. 12) 
Hoje, vivemos a cibercultura. O usuário atual da internet é diferente do de alguns anos atrás; ele busca, por meio de vários mecanismos, a informação que demanda, saindo da posição aparentemente passiva de "receptor" da informação. É nesse universo em que as fake news emergem e se proliferaram.

O termo fake news, que, segundo o dictionary.cambridge.org, significa "histórias falsas que parecem ser notícias, que se espalham na internet ou usam outras mídias, geralmente criadas para influenciar pontos de vista políticos", tornou-se corriqueiro nas redes sociais digitais. Essas notícias falsas chegam, normalmente, por meio de compartilhamentos ou curtidas - muitas vezes sem a clara identificação do responsável pela veiculação - em uma rede comunitária de usuários que se identificam.

Sendo assim, pode-se gerar a hipótese de que um veiculador de fake news, identificado aqui como uma instância de informação, é um ente influenciador aceito por uma rede comunitária digital sociointerativa, o que implica o recompartilhamento da informação, muitas vezes, sem o mínimo de legitimidade: característica psicológica vulgarmente conhecida na internet como efeito manada - a tendência de as pessoas seguirem um grande influenciador ou mesmo um determinado grupo apenas por adesão de uma maioria ou por empatia, sem que isso passe, necessariamente, por uma reflexão individual.

Associando essas informaçóes à ubiquidade da internet, temos um fenômeno chamado de superinformaçâo (CHARAUDEAU, 2006): as pessoas recebem notícias em excesso de maneira multidirecional, levando a uma saturação que tem como consequência a diminuição na qualidade da informação e a destruição na crença da verdade.

No entanto, um dos fatores essenciais para justificar a natureza viral da fake new encontra-se nas palavras de Marcuschi (2010, p.150):

Tratando-se da aquisição rápida da informação, a internet dispõe de um recurso democrático, que são os chamados links, isto é, ao clicar sobre eles, o computador faz uma busca automática, de uma imgem ou documento, estejam onde estiverem, em qualquer lugar do mundo. E, para isso, não há necessidade de se saber, caso não seja importante, de onde vem a informação. 
Nesse sentido, o objetivo deste artigo é, na perspectiva da teoria da Análise Semiolinguística do Discurso, de Patrick Charaudeau, analisar um exemplo de fake new, a fim de evidenciar as intencionalidades psicosociodiscursivas que determinam as orientaçóes discursivas expressas pelas visadas, bem como os procedimentos de construção enunciativa de ordem linguística que explicitam os diferentes tipos de relaçóes do ato enunciativo de caráter informativo, inserindo-o no quadro de semiotização do mundo, por meio do contrato de comunicação (CHARAUDEAU, 1995).

\section{A Teoria Semiolinguística}

De acordo com a teoria Semiolinguística de Análise do Discurso, criada pelo pesquisador Patrick Charaudeau, todo ato de linguagem é uma encenação - mise-en-scène - que comporta quatro protagonistas, sendo dois situacionais, externos, e dois discursivos, internos. Os sujeitos "externos" são o EUc (eu-comunicante) e o TUi (tu-interpretante), e os sujeitos "internos", o EUe (eu-enunciador) e o TUd (tu-destinatário).

No gênero notícia (postagem) de Facebook, o EUc (eu-comunicante) é o comentarista/jornalista/internauta (a pessoa física). Nesse sentido, tendo em mente um TUd, o EUc produz um texto que é posto em cena pelo EUe. O objetivo final é influenciar o TUi.

FIG.1- Os dois circuitos do ato de linguagem.

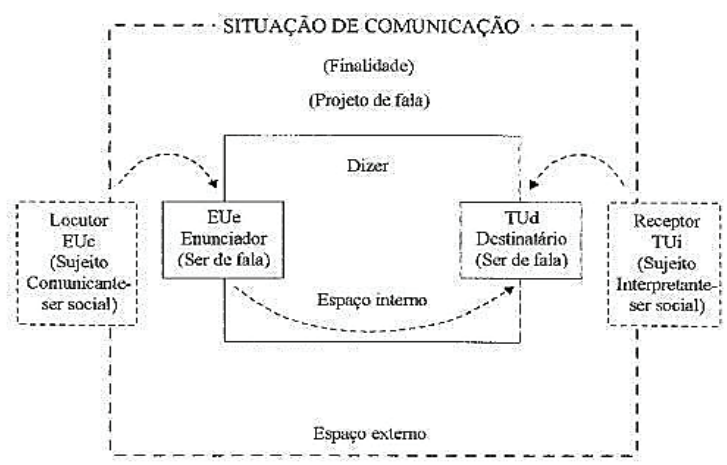

Fonte: CHARAUDEAU, 2008, p. 52. 
Além dos dois componentes centrais - sujeito comunicante e seu interlocutor, o dispositivo do ato de linguagem também é composto, segundo Charaudeau (2008, p. 68), por: situação de comunicação - local onde se encontram os parceiros da troca linguageira, determinados por uma identidade psicossocial e ligados por meio de um contrato comunicativo; modos de organização do discurso - princípios de organização do conteúdo linguístico que dependem da finalidade comunicativa do sujeito-falante, enunciar, descrever, narrar, argumentar; língua - material verbal estruturado em categorias e dotado simultaneamente de forma e sentido; texto - o resultado material do ato de comunicação, fruto das escolhas (conscientes ou não) do sujeito-comunicante sobre as categorias de língua e os modos de organização do discurso em função das restrições da situação.

Os modos de organização do discurso são procedimentos discursivos que se realizam no uso das categorias supracitadas, na organização do mundo referencial, em função de certas finalidades discursivas do ato comunicativo. Temos interesse em destacar o modo enunciativo, uma vez que participa da construção de todos os demais, dando conta da posição que o sujeito falante ocupa em relação ao seu interlocutor. Assim, de acordo com as intençóes do sujeito falante, distinguem-se três comportamentos no modo enunciativo: o alocutivo, o elocutivo e o delocutivo (CHARAUDEAU, 2008, p. 82).

No comportamento alocutivo, o sujeito comunicante assume seu ponto de vista, implicando o interlocutor com seu modo de dizer e impondo-lhe um comportamento, de acordo com o tipo de relação estabelecida pelo contrato comunicativo: (A) relaçâa de superioridade, por meio das modalidades de interpelação, injunção, autorização, sugestão, proposta, julgamento ou aviso; e (B) relação de inferioridade, por meio das modalidades de petição ou interrogação.

No comportamento elocutivo, o sujeito falante enuncia seu ponto de vista sobre o mundo, modalizando subjetivamente o verdadeiro propósito do enunciado, sem que o interlocutor esteja implicado nessa tomada de posição. Esse ponto de vista sobre o mundo pode ser expresso por meio de: (A) um modo de saber, com as modalidades de constatação e de saber/ignorância; (B) uma avaliação, com as modalidades de opiniāo e de apreciação; (C) uma motivação, com as modalidades de obrigação, possibilidade e querer; (D) um enga- 
jamento, com as modalidades de promessa, aceitação/recusa, acordoldesacordo e declaração; e (E) uma decisão, com a modalidade de proclamação.

Já no comportamento delocutivo, o sujeito falante apaga-se de seu ato de enunciação, com vistas a simular uma aparente objetividade, não implicando também o interlocutor. Nesse caso, apresentam-se duas possibilidades: (A) quando o propósito se impóe por si só, expresso pela asserção, nas modalidades de evidência ou probabilidade; e (B) quando o propósito é um texto de outrem, expresso nesse caso pela modalidade de discurso relatado.

Assim, para informar e até mesmo incitar, o sujeito comunicante pode colocar em evidência, em seu texto, um determinado comportamento. Ele tem por objetivo transformar um acontecimento bruto em um acontecimento interpretado para a instância receptora. Por isso, Charaudeau (2006) afima não transmitirem as mídias o que ocorre na realidade. $\mathrm{O}$ acontecimento que chega para o leitor já foi filtrado e, por isso, interpretado pela instância midiática.

FIG. 2 - Contrato de comunicação midiático

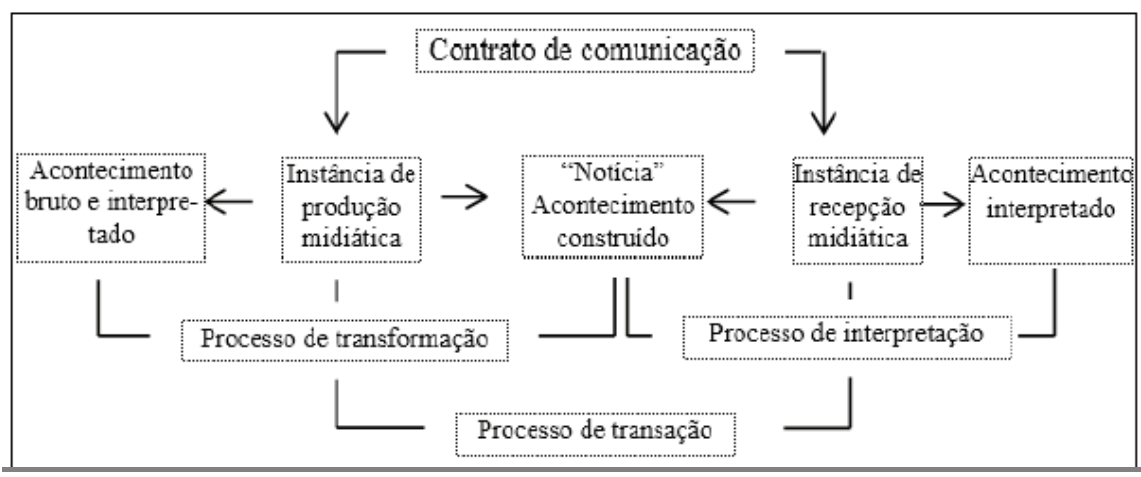

Fonte: CHARAUDEAU, 2006, p.114.

Para informar, segundo Charaudeau (2006), são necessários três elementos básicos - uma fonte, um receptor e um tratamento dado à informação, e daí decorrem alguns questionamentos: qual a validade da informação? O que será selecionado para informar? Qual a pertinência da informação? Qual o valor de 
verdade da informação? Qual o grau de ignorância do informado diante da informação? Como atingir o receptor? Quais fatos serão selecionados em função do alvo? Quais serão as escolhas discursivas efetuadas por aquele que informa?

Vale ressaltar que o caráter manipulatório, tantas vezes associado à mídia, acontece justamente nessa encenação discursiva, em que o sujeito comunicante fará a escolha das estratégias de composição textual, com vistas a atingir um determinado interlocutor.

Segundo Charaudeau (2006), a maneira como o homem perspectiva seu olhar é responsável pela organização do seu saber: com o olhar para "fora", voltado para o mundo, ele organiza seu saber objetivamente em categorias de conhecimento; com o olhar para si mesmo, ele organiza seu saber subjetivamente em categorias de crença.

Assim, os saberes de conhecimento nascem de uma representação racionalizada da existência dos seres e dos fenômenos sensíveis do mundo, passando por filtros sociais e culturais, com auxílio de aparatos intelectuais formais. Já os saberes de crença nascem do olhar subjetivo que o sujeito lança sobre o mundo, quando ele se volta a comentá-lo. As crenças são responsáveis pela regulação das práticas sociais, ao criarem normas efetivas e, ao mesmo tempo, dos ideais de comportamento, ao regularem os discursos de representação produzidos no âmbito do grupo social.

Segundo Charaudeau (2006, p. 46),

quando essas crenças se inscrevem numa enunciação informativa, servem para fazer com que o outro compartilhe os julgamentos sobre o mundo, criando assim uma relação de cumplicidade. Ou seja, toda informação a respeito de uma crença funciona ao mesmo tempo como interpelação do outro, pois o obriga a tomar posição com relação à avaliação que lhe é proposta, colocando-o em posição reativa - o que não é necessariamente o caso de informação que se refere aos conhecimentos [...]

Nesse sentido, valor de verdade é diferente de efeito de verdade, ainda que ambos sejam frutos de um julgamento. Charaudeau (2006, p. 49) postula que o valor de verdade náo é de natureza empírica, pois 
se realiza através de uma construção explicativa elaborada com a ajuda de uma instrumentação científica que se quer exterior ao homem [...] que pode definir-se como um conjunto de técnicas de "saber dizer", de "saber comentar" o mundo. A utilização dessa instrumentalização permite construir um "ser verdadeiro" que se prende a um saber erudito produzido por textos fundadores.

Diferentemente, o efeito de verdade está relacionado mais ao "acreditar ser verdadeiro" que ao "ser verdadeiro":

Surge da subjetividade do sujeito em sua relação com o mundo, criando uma adesão ao que pode ser julgado verdadeiro pelo fato de que é compartilhável com outras pessoas, e se inscreve nas normas de reconhecimento do mundo. Diferentemente do valor de verdade, que se baseia na evidência, o efeito de verdade se baseia na convicçáo, e participa de um movimento que se prende a um saber de opiniáo, a qual só pode ser apreendida empiricamente, através dos textos portadores de julgamentos. $\mathrm{O}$ efeito de verdade não existe, pois, fora de um dispositivo enunciativo de influência psicossocial, no qual cada um dos parceiros da troca verbal tenta fazer com que o outro dê sua adesão a seu universo de pensamento e de verdade. O que está em causa aqui não é tanto a busca de uma verdade em si, mas a busca de "credibilidade", isto é, aquilo que determina o "direito à palavra" dos seres que se comunicam, e as condiçóes de validade da palavra emitida. (CHARAUDEAU, 2006, p. 49)

Quanto à finalidade psicosociodiscursiva, a fake new é uma notícia falsa, uma "mentira", que tem, entre outras intençóes, a de manipular a opinião da instância de recepção, construindo valores que subjazem às informaçóes veiculadas. Entretanto, ainda que as mídias não possam ser entendidas como instâncias manipuladoras, por não prescreverem, de forma explícita, regras de comportamento, é pelo trato discursivo, no uso dos signos internos da língua, que atribuem sistemas de valores às informaçóes. 
A fim de ilustrar a mise-en-scène discursiva da fake news, descrevemos a estratégia do discurso da "mentira" (CHARAUDEAU, 2008, p. 53):

- $\quad$ EUe diz $p$.

- EUc sabe (pensa) não $p$.

- $\quad$ EUc faz com que TUi se identifique com um TUd que acredita que EUc pensa $p$ (grau de credibilidade).

Quanto à identidade dos sujeitos da comunicação e suas representaçóes de ordem linguística, temos como instância informante, na posição do "eu" comunicante, o internauta que compartilha uma postagem do estadao.com e, como instância de recepção, na posição de um "tu" destinatário, os usuários da rede social Facebook.

\section{A fake news e a desinformação: análise de uma postagem}

Philippe Breton (1999) descreve que, embora a estratégia de desinformação seja utilizada há tempos, apenas no século XX atingiu capital importância. Segundo Breton, o uso comum atribui atualmente à desinformação o sentido de informação incorreta, utilizada para mascarar fatos.

Neste artigo, a estratégia de desinformação, representada pela fake news, é uma ação que consiste em tornar válida certa descrição do real favorável ao sujeito comunicante, fazendo-a passar por uma informação segura e verificada. Toda habilidade técnica da desinformação reside justamente no mecanismo que permite encenar uma informação "falsa" como uma informação "verdadeira", que seja perfeitamente "crível" e que oriente a ação daquele que a recebe.

A manipulação, nesse sentido, seria o resultado de uma visada discursiva de incitação de agir: quando se está numa situação em que há necessidade do outro para realizar um projeto e não se tem autoridade sobre esse outro para obrigá-lo a agir de uma determinada forma. Essa manipulação é acompanhada de uma falsidade, pelo fato de que há uma relação entre um influenciador-manipulador, que esconde sua intenção, e um influenciado-manipulado, que a ignora, como veremos na postagem a seguir. 
A postagem da figura 3, de 28/03/2019, foi divulgada no Facebook como se fosse uma notícia atual, com mais de 1,6 mil compartilhamentos.

FIG. 3 - Postagem de facebook sobre o juiz Sérgio Moro.

\section{- 28 de março às 19:15}

Sérgio Moro acaba de ser escolhido o décimo-terceiro maior líder do mundo pela americana Fortune!

O ranking é composto por apenas 50 nomes, dentre eles, Papa Francisco e Angela Merkel.

Moro foi comparado a Elliot Ness, que derrubou o império do mafioso Al Capone nos anos 50 .

Um tapa de luvas naqueles que tentam ainda denegrir a imagem de nosso juiz.

Todo o nosso apoio e gratidão a Sérgio Moro.

Quero 1 milhão de compartilhamentos, meus amigos !!

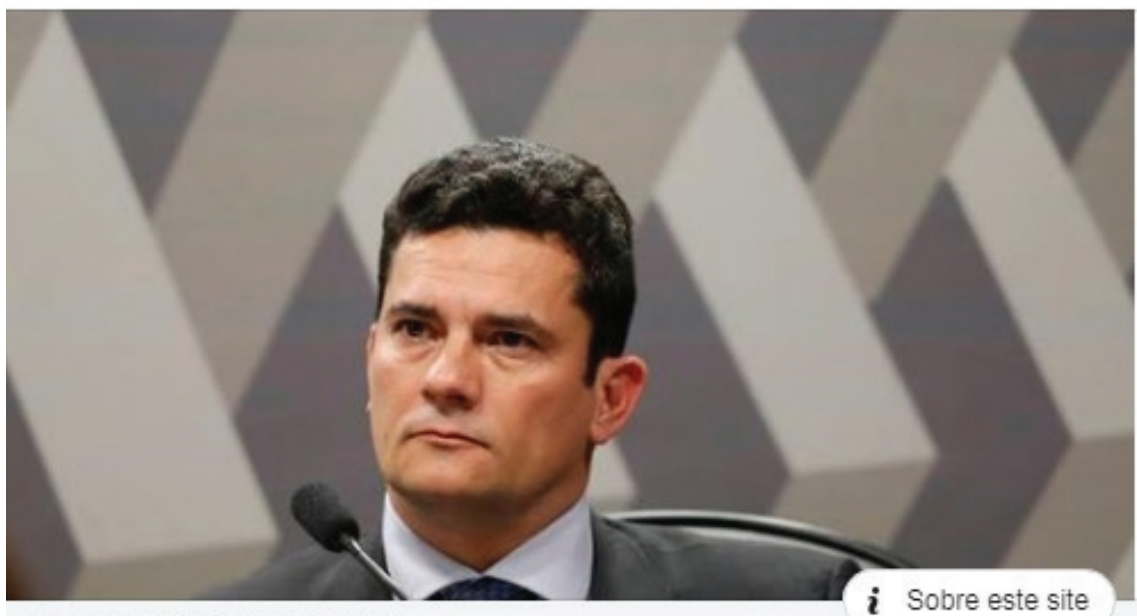

POLITICA.ESTADAO.COM.BR

Moro é considerado pela 'Fortune' o $13^{\circ}$ maior líder mundial Política - Estadão

Fonte: https://web.facebook.com/search/?q=MORO $\% 20 \%$ C3\%89\%20O\%2013\%C2\%BA\% 20MAIOR20LIDER\%20DO\%20MUNDO\&searchtype=posts\&epa=SERP_TAB. Acesso em 09/04/2019. 
A informação da postagem, em 2016, era verdadeira. Na ocasião, Sérgio Moro era juiz e não ministro da justiça. A última lista da revista Fortune é de 2018 e dela não consta o nome do atual ministro, como o próprio site politica. estadao justifica:

Sérgio Moro ainda não era ministro da Justiça e da Segurança quando foi eleito um dos "maiores líderes do mundo" pela revista Fortune. Um boato enviado por leitores ao WatsApp do Estadâo Verifica [...] traz a informação falsa de que o ex-juiz teria acabado de ser escolhido para receber a homenagem - o fato, no entanto, ocorreu em 2016. (MONNERAT; NETTO, 2019, n/p, grifo do site)

A postagem de 2016 do politica.estadao.com.br foi compartilhada por um internauta como se fosse uma notícia atual. Para os leitores de Facebook, parece uma notícia crível, tendo em vista a legitimidade que é dada pela fonte politica.estadao.

No início da postagem, "Sérgio Moro acaba de ser escolhido o décimo-terceiro maior líder do mundo pela americana Fortune! O ranking é composto por apenas 50 nomes, dentre eles, Papa Francisco e Angela Merkel. Moro foi comparado a Elliot Ness, que derrubou o império do mafioso $\mathrm{Al}$ Capone nos anos 50.", percebe-se a modalidade delocutiva, em que um eu-comunicante (internauta) testemunha a maneira como os discursos do mundo (provenientes de um terceiro, neste caso, do estadao.com) se impóem a ele. "O resultado é uma enunciação aparentemente objetiva (no sentido de 'desvinculada da subjetividade do locutor’) que faz a retomada, no ato de comunicaçáo, de Propósitos e Textos que não pertencem ao sujeito falante (ponto de vista externo)." (CHARAUDEAU, 2008, p. 83). No entanto, é o próprio Charaudeau que chama a atenção para o fato de que:

o ato de enunciação que descreve a "relação com um terceiro" é de fato peculiar. Sabemos que todo ato de linguagem depende, de um modo ou de outro, do sujeito falante e de seus diferentes pontos de vista. 
Trata-se, portanto, de um "jogo" protagonizado pelo sujeito falante, como se fosse possível a ele não ter ponto de vista, como se pudesse desaparecer por completo do ato de enunciação e deixar o discurso falar por si. (CHARAUDEAU, 2008, p. 84, grifo do autor)

Ainda nesse início da postagem, percebe-se a relevância que o eu-comunicante quer dar ao fato, ao dizer que, do ranking de que consta o nome do juiz Sérgio Moro, constam também o nome de personalidades, como o do Papa Francisco e o da Angela Merkel (Chanceler Federal da Alemanha desde 2005). Além disso, ainda se afirma que Moro foi comparado a Elliot Ness, que derrubou o império do mafioso Al Capone nos anos de 1950. Tudo isso para enaltecer a pessoa do juiz Sério Moro.

Assim, levando em consideração que o eu-comunicante é o internauta que compartilha a antiga postagem do Estadão, na passagem "Um tapa de luvas naqueles que tentam ainda denegrir a imagem de nosso juiz. Todo o nosso apoio e gratidão a Sérgio Moro.”, o procedimento linguístico utilizado pertence à modalidade da "opiniāo", do modo elocutivo. O locutor pressupóe uma informação e explicita a posição que a informação assume em seu universo de crença, por meio da atitude de convicção, já que exprime certeza sobre o fato. Essa convicção assume configuração implícita por meio do tom afirmativo da sentença.

Em "nosso juiz" e "nosso apoio", o emprego do pronome possessivo de primeira pessoa do plural implica, indiretamente, o leitor e procura criar uma atmosfera de proximidade. O juiz não é apenas do internauta, mas também do leitor.

Por fim, no último trecho da postagem - "Quero 1 milhão de compartilhamentos, meus amigos!!”-, constata-se o emprego da modalidade de "proposta"- que pertence ao modo alocutivo - e da modalidade "querer" - que pertence ao modo elocutivo. Ao utilizar a primeira pessoa verbal, "quero", e o pronome possessivo também de primeira pessoa, "meus", o eu-comunicante enuncia o seu ponto de vista sobre o mundo. No entanto, ao final, implica o interlocutor, chamando-o de "amigo". Dessa forma, o eu-comunicante estabelece, com seu enunciado, uma ação a realizar que pode ser efetivada em 
conjunto com o interlocutor, com vistas a benefício mútuo ou de outrem, pressupondo um poder fazer para ambos. O interlocutor recebe uma oferta em forma de "proposta de fazer" da qual ele deve ser beneficiário, cobeneficiário ou altruísta.

Assim, o internauta que replica a informação tem por objetivo informar: um "eu", nesse caso, não legitimado, quer "fazer saber" a um "tu", que se encontra na posição de "dever saber" sobre um determinado fato.

Nesse sentido, há o predomínio de duas visadas discursivas - intencionalidade psicosociodiscursiva que determina a expectativa do ato de linguagem do sujeito comunicante e, por conseguinte, da própria troca linguageira, a de informação e a de incitação.

$\mathrm{Na}$ visada de informação, o EU quer "fazer saber", e ele está legitimado em sua posição de saber; $T U$ encontra-se na posição de "dever saber" alguma coisa sobre a existência dos fatos, ou sobre o porquê ou o como de seu surgimento. Na postagem, como o eu-comunicante não é um jornalista, ele busca legitimidade ao replicar uma publicação do estadao.com.

Já na visada de incitação, o EU quer "mandar fazer", mas não se encontra em posição de autoridade para isso, restando a opção de incitar a fazer; ele deve, então, "fazer acreditar" ao $T U$ que ele terá benefícios em razão desse ato; $T U$ está, então, em posição de "dever acreditar" que ele age para seu próprio bem. (CHARAUDEAU, 2004, n/p.)

Dessa forma, na postagem em análise, além de informar, tem-se o objetivo de incitar, de provocar o outro, a fim de que ele se sinta coautor da postagem. O "internauta-comentarista" coloca-se numa posição de aliado do leitor, como se estivesse informando algo para o bem da população.

\section{Concluindo}

A postagem em análise é apenas um exemplo entre tantas notícias falsas que tem, sobretudo, a intenção de manipular a opinião da instância de recepção, construindo valores que subjazem às informaçóes veiculadas, ainda que as mídias não possam ser entendidas como instâncias manipuladoras, por não prescreverem, declaradamente, regras de comportamento, norma ou sanção. 
A fake news é um instrumento de desinformação, com latente potencial para ser utilizada como ferramenta de detração por qualquer instância política.

Pelo processo de transformação entre o mundo a significar e o mundo significado, verificamos que sistemas de valores, organizados por saberes de crença, são atribuídos às informaçóes, a fim de construir discursivamente normas de referência no imaginário social, ao passo que manipulam a opinião da coletividade com vistas a homogeneizá-la.

É importante lembrar que os saberes de crença, embutidos na fake news, se inscrevem numa enunciação informativa para fazer com que o público, instância receptora, compartilhe os julgamentos, por meio de uma atitude de cumplicidade induzida, uma vez que o público se sente beneficiado, ao sair do estado de ignorância por meio desse saber.

Como esse tipo de saber pertence a um dispositivo enunciativo de influência psicossocial que se insere no universo da crença, a instância receptora adere à informação, porque "acredita ser verdadeiro", incorporando ou submetendo-se a um efeito de verdade.

\section{Referências}

BRETON, Philippe. A manipulação da palavra. Trad. Maria Stela Gonçalves. São Paulo: Ediçôes Loyola, 1999.

CHARAUDEAU, Patrick. A conquista da opinião pública: como o discurso manipula as escolhas políticas. Trad. Ângela M. S. Corrêa. São Paulo: Contexto, 2016. 2006.

. Discurso das mídias. Trad. Ângela M. S. Corrêa. São Paulo: Contexto,

. Visadas discursivas, gêneros situacionais e construção textual. In: MACHADO, Ida Lúcia; MELLO, Renato de. (org.) Gêneros: reflexôes em análise do discurso. Belo Horizonte: Núcleo de Análise do Discurso - FALE/UFMG, 2004, p. 13-39.

. Une analyse sémiolinguistique du discours. Langages: les analyses du discours en France, no 117. Paris, Larousse, mars 1995, n/p.

. Linguagem e discurso. Coord. Trad. Ângela M. S. Corrêa; Ida Lúcia Machado. São Paulo. Contexto, 2008 
CHOMSKY, Noam. Midia: propaganda política e manipulação. Trad. Fernando Santos. São Paulo: Editora WMF Martins Fontes, 2013.

FAKE NEWS. In: dictionary.cambridge.org. Disponível em: $<$ https://dictionary.cambridge.org/dictionary/english/fake-news $>$ Acesso em 03/01/19.

LEMOS, André. Cibercultura: tecnologia e vida social na cultura contemporânea. Porto Alegre: Sulina, 2015.

MARCUSCHI, Luiz Antônio. Gêneros digitais emergentes no contexto da tecnologia digital. In: MARCUSCHI, Luiz Antônio; XAVIER, Antônio Carlos (org.) Hipertexto e gêneros digitais: novas formas de construção de sentido. São Paulo: Cortez, 2010, p. 13-67.

MONNERAT, Alessandra; NETTO, Paulo Roberto. Moro não era ministro quando foi eleito um dos "maiores líderes do mundo" pela revista "Fortune". In: politica.estadao, 28 março 2019. Disponível em: <https://politica.estadao. com.br/blogs/estadao-verifica/moro-nao-era-ministro-quando-foi-eleito-um-dos-maiores-lideres-do-mundo-pela-revista-fortune/>. Acesso em 3/10/2019.

\title{
FAKE NEWS: A SEMIOLINGUISTIC EXAM OF THE LACK OF INFORMATION IN SOCIO-INTERACTIVE DIGITAL ENVIRONMENTS
}

\begin{abstract}
The present study aims to examine, in the light of the Semiolingustic Theory of Patrick Charaudeau, in a facebook post, the psycho-socio-discursive intentions that determine the discursive orientations expressed by purposes, as well as the procedures of enunciative construction of linguistic nature that explain the different types of relations of the enunciative act.
\end{abstract}

KEYWORDS: Semiolinguistic; Purposes; Fake News. 
